ISSN 1392-3196 / e-ISSN 2335-8947

Zemdirbyste-Agriculture, vol. 106, No. 2 (2019), p. 173-182

DOI 10.13080/z-a.2019.106.023

\title{
Effects of winter and spring rape seed treatment with neonicotinoids on honey bees
}

\author{
Romualdas ZEMECKIS ${ }^{1}$, Anželika DAUTARTE் ${ }^{1}$, Justinas KRETAVIČIUS ${ }^{1}$, \\ Jolanta DROŽDZ ${ }^{2}$ \\ ${ }^{1}$ Vytautas Magnus University Agriculture Academy \\ Studentų 11, Akademija, Kaunas distr., Lithuania \\ E-mail: romualdas.zemeckis@vdu.lt \\ ${ }^{2}$ Vilnius University \\ Universiteto 3, Vilnius, Lithuania
}

\begin{abstract}
Potential impacts of neonicotinoids (thiamethoxam and clothianidin) on honey bees (Apis mellifera L.) were explored in 2016-2018. The study aimed to evaluate the effects of thiamethoxam and clothianidin used for seed treatment of winter and spring rape (Brassica napus L.) on honey bees under Lithuanian conditions and to quantify the levels of neonicotinoids in the dust released during the sowing operation. Honey bee colonies were established for further field testing and sample collection. The samples of nectar, pollen and bee bread were analysed for neonicotinoid residues.

The potential impact of the seed treatment with thiamethoxam and clothianidin on the normally developed bee colonies was investigated in 2017 and 2018. The obtained findings suggest that when sowing neonicotinoid-treated winter and spring rape seed in a dry soil, the concentrations of neonicotinoids in the dust released during the sowing operation were three times as high as the maximum permitted limit $\left(0.05 \mathrm{mg} \mathrm{kg}^{-1}\right)$ set by the European Committee for bee products. The residue levels of neonicotinoids detected in the honey, pollen and bee bread samples were minimal $\left( \pm 0.01 \mathrm{ng} \mathrm{g}^{-1}\right)$. However, no evidence was found to indicate the negative effects of the nicotinoid-seed treatment on the development of bee colonies, wintering, well-being, and honey production.
\end{abstract}

Key words: Apis mellifera, crop pollination, crop protection, neonicotinoids, risk assessment.

\section{Introduction}

Neonicotinoids are active substances used in plant protection products to control harmful insects and parasites. Neonicotinoids are much more toxic to invertebrates, such as insects, than to mammals, birds and other higher organisms. They affect the central nervous system of insects, resulting in paralysis and death.

Neonicotinoids currently account for approximately one third of the global insecticide market; annual imidacloprid global production was approximately 20000 tonnes of active substance in 2010 (Simon-Delso et al., 2015). Neonicotinoids are systemic pesticides. Unlike contact pesticides that remain on the surface of treated leaves, systemic pesticides are taken and transferred to all plant tissues (roots, stems, leaves, flowers), and get into nectar and pollen. Their physicochemical properties are preeminent to the insecticides of the previous generation (i.e. organic phosphorus compounds, carbamates, pyrethroids, etc.) and they pose less risk to operators and consumers. Due to the systemic nature of neonicotinoids, they are absorbed by roots or through leaves and continue to move to all parts of the plant which, in turn, become poisonous for herbivore insects. The toxicity lasts for an uneven period depending on the plant, its growth stage and the rate of the pesticide applied.

Neonicotinoids are active against many economically important plant pests, including Aphidae, Aleyrodidae, Cicadellidae, Chrysomelinae, Elateridae, Fulgoroidea and Pseudococcidae (Elbert et al., 2008; Jeschke et al., 2011). Some of these pests (e.g., aphids) can also transfer the viruses, so neonicotinoids can also contribute to the control of insect vectors of crop viral diseases. However, neonicotinoids cause adverse effects on non-target insects (Maini et al., 2010; Hayasaka et al., 2012; Lu et al., 2012; 2014; Fogel et al., 2013; Matsumoto, 2013; Sanchez-Bayo et al., 2013; Van der Sluijs et al., 2013; Feltham et al., 2014). While a relatively small number of bee species play a dominant role in pollinating crops (Kleijn et al., 2015), the ability to pollinate plants is generally dependent on the

Please use the following format when citing the article:

Zemeckis R., Dautarte A., Kretavičius J., Droždz J. 2019. Effects of winter and spring rape seed treatment with neonicotinoids on honey bees. Zemdirbyste-Agriculture, 106 (2): 173-182. DOI 10.13080/z-a.2019.106.023 
viability of the entire insect community (Brittain et al., 2013; Woodcock et al., 2014). Measures and actions protecting bee communities are important for the highagro-load landscape; no less important is the ability of insect communities to maintain pollination at a stable level (Garibaldi et al., 2013). It is clear that national management strategies are necessary to ensure the stability of this community, directed towards the longterm preservation of the viability of wild bee populations in time and space. The role of other environmental components is also important: a full range of factors, ranging from land use to climate change, can interact with neonicotinoid effects and indirectly affect the viability of wild bee populations (Winfree et al., 2009; Potts et al., 2010; Ollerton et al., 2014).

Woodcock et al. (2017) study on wild bees showed a significant negative effect of neonicotinoids on insect species regularly feeding on the rape crop. A negative correlation between the viability and neonicotinoid exposure has been identified in both cases. The negative effects of neonicotinoids were found to be three times higher on insect species feeding on rape compared to the species feeding on other crops. Therefore, while neonicotinoid seed treatments on oilseed rape are correlated with a reduction in population persistence, for some wild bees this effect has not led to population extinction at a national scale. The study has concluded that the dose of the neonicotinoids alone is responsible for a loss greater than $20 \%$ of the insect pollinators Halictus tumulorum, Lasioglossum fulvicorne, L. malachurum, L. pauxillum and Osmia spinulosa since 2002 . The vitality of the species that feed on rape positively correlates with the volumes of rape areas. This shows that only the species that feed on rape benefit from the presence of rape in the landscape. However, the benefit of the rape crop does not compensate for the adverse effects of the neonicotinoid dose (Woodcock et al., 2017).

In 2014, a study was conducted in North Germany on rape seeds treated with clothianidin. The study investigated the amount of pesticide residues in the nectar and honey, the composition of pollen collected by bees, the potential adverse effects on bumble bees and bees, the strength and development of colonies, and honey production. The findings revealed no adverse effects on these insects (Heimbach et al., 2016; Rolke et al., 2016; Schmuck, Lewis, 2016; Sterk et al., 2016). A similar study conducted in Estonia in 2013-2014 by Karise et al. (2017) found that the concentration of all pesticide residues was lower than the lethal dose for honey bees. Nevertheless, it was found that honey was contaminated not only with the pesticides used for oilseed rape. Pesticides are believed to accumulate in the soil and surface water. Wild and uncultivated plants close to the crop field would also be contaminated with pesticides. The average total quantity of pesticide residue in honey is set at around $25 \mu \mathrm{g} \mathrm{kg}^{-1}$. This means that bee food (pollen and nectar) is contaminated not only directly by cultivated plants but also through contaminated soil.

Alarge-scale field testing experiment (Woodcock et al., 2017) was carried out in Hungary, Germany and United Kingdom on the potential effects of neonicotinoids on three types of pollinators in these countries. Winter rape seeds treated with neonicotinoids (thiamethoxam and clothianidin) were tested and compared to the control group, in which the seeds were not treated. The negative effects of neonicotinoids on honey bees were observed in Hungary and United Kingdom, while no effect was observed in Germany. In Hungary, clothianidin had a negative impact on bee wintering, especially in weak bee colonies. It was found that during wintering, 24\% of colonies had deteriorated. The reproductive cycle of wild bees (bumblebees and Osmia bicornis) was reduced by the negative effect of neonicotinoid residues. It has been noted that neonicotinoids reduce the recovery of insect pollinators' population in the following year after exposure to pesticides. A significant variation in adverse effects has also been identified. It is related to the overall bee health, diet and immunity, which are important factors for the occurrence of negative effects of neonicotinoids.

The overall purpose of the present study was to evaluate the effects of active substances (thiamethoxam and clothianidin) belonging to the neonicotinoid class used for the treatment of winter and spring rape seed on honey bees (Apis mellifera L.) under Lithuanian climate conditions. The specific purposes of the study included (1) the determination of the concentration of neonicotinoid residues in rape pollen, nectar and bee bread; (2) the determination of neonicotinoid possible dustiness during sowing and the effect of dust on honey bees; and (3) the evaluation of the effects of neonicotinoids on the development, wintering and productivity of bee colonies.

\section{Materials and methods}

Experimental conditions. The impact of winter and spring rape seed treatment with neonicotinoids on honey bee vitality, and neonicotinoid residues in rape pollen, nectar and bee bread were investigated in 2016-2018 at Vytautas Magnus University Agriculture Academy. The research provides a methodology for the establishment of bee colonies, the setting of test fields and the determination of neonicotinoid residues in nectar, pollen and bee bread. The impact of neonicotinoids on honey bees was observed in fully developed bee colonies after overwintering. In the summer of 2017 and 2018 (June and July), the effects of neonicotinoids on bees were investigated during the flowering stage of spring rape (Brassica napus L.). Spring and winter rape seeds were dressed simultaneously with two tested neonicotinoids - thiamethoxam and clothianidin. As sources of these two neonicotinoids, two insecticides: a.i. beta-cyfluthrin $80 \mathrm{~g} \mathrm{l}^{-1}+$ clothianidin $400 \mathrm{~g} \mathrm{l}^{-1}$ and thiamethoxam $280 \mathrm{~g} \mathrm{l}^{-1}$ + fludioxonil $8.0 \mathrm{~g} \mathrm{l}^{-1}+$ metalaxyl-M $32.3 \mathrm{~g} \mathrm{l}^{-1}$ (Syngenta International $\mathrm{AG}$, Switzerland) were used. Individual dose used for dressing each seed was calculated. Theoretical content of clothianidin was $20 \mu \mathrm{g}$ and thiamethoxam $12.6 \mu \mathrm{g}$ per seed.

Bee colonies. New colonies of honey bee (Apis mellifera carnica) were established in order to obtain representative and accurate data and to eliminate the effects of neonicotinoid residues from the previous years accumulated in the combs. In 2016, a total of 18 artificial swarms were formed only from adult bees without using 
brood and honey combs without food reserves. Each hive contained $1 \mathrm{~kg}$ of adult bees with new honeycomb wax foundations and was supplemented with $2.5 \mathrm{~kg}$ of sugar paste - dough Apifonda ${ }^{\circledR}$ (Nordzucker AG, Germany). Each newly formed colony had about 10,000 adult bees. They were placed in a Langstroth type polystyrene hive, which can hold up to 10 frames on one hive body with honeycombs. Among the honeycombs there are 10 bee spaces and they can hold up to 20 thousand adult bees. Estimating the number of honeycombs covered with bees, the total bee number and colony strength in the hive were calculated. It is considered that in one bee space there are about 2000 adult bees. The number of bees and health of the brood were determined during the inspection by evaluating each honeycomb with bees separately. The data for statistical analysis of colony strength were calculated using the number of frames with bees.

In August 2016, bee colonies were transported for the wintering to the bee overwintering place at Palimšys in Kaišiadorys district, Lithuania. Bee colonies were fed with $18 \mathrm{~kg}$ of $60 \%$ concentration sugar syrup. In late autumn, the colonies were treated with acaricide (amytrase) by using fumigating method. An overwintering index was calculated in the spring of 2017. The bee colonies formed in 2016 were used to investigate the effects of neonicotinoids in 2017. The same colonies, tested in spring rape in 2017, were used for the investigation in winter rape in 2018. The colonies used in 2018 in the control group and in test groups were formed in 2017 in the same way. From the colonies that were re-used for neonicotinoid tests in the next year, all honey and bee bread reserves were taken away, the bees were fed with sugar syrup only in order to prevent bee colonies from having contact with neonicotinoids.

Bee hives for the 2017 experiment were deployed in the following sites: 6 bee hives at Noreikiškès, Kaunas district (Experimental Station of Vytautas Magnus University Agriculture Academy), in the winter rape crop (treated seeds), 6 bee hives at Paliepis, Kaišiadorys district, in the spring rape crop (treated seeds) and 6 bee hives as the control (spring rape crop sown with untreated seeds) at Palimšys, Kaišiadorys district. In 2018, bee hives were deployed as follows: 7 bee hives at Paliepis, Kaišiadorys district, in the winter rape crop (treated seeds), 10 bee hives at Kaišiadorys in the spring rape crop (treated seeds) and 6 bee hives as the control (untreated seeds) at Noreikiškès, Kaunas district. The potential impact of neonicotinoids on normally developed bee colonies was investigated in 2017 and 2018.

Overwinter survival rate assessment was carried out in the spring of 2018. The overwintering index (OI) was calculated according to the following formula: in autumn.

$\mathrm{OI}=$ number of bees in spring / number of bees

When this indicator is closer to 1 , the bee colonies are better overwintering. In April 2017, during the first inspection of the hives, OI was evaluated for the first time.

Determination of neonicotinoid residues. Neonicotinoid residues were identified in nectar, pollen, bee bread and soil dust in 2016-2018. The nectar samples were collected from the uncapped honeycomb using a 10 $\mathrm{ml}$ disposable syringe with a rabbled and grinded needle of $1.2 \mathrm{~mm}$ outside thickness. This type of needle was made from a medical syringe needle by us. A total of 10 $\mathrm{ml}$ of nectar was taken from each colony. The syringe filled with nectar was placed in a portable cooling bag with ice. In the evening the syringes containing nectar were transferred to a refrigerator and frozen at $-18^{\circ} \mathrm{C}$. When it was difficult to take the nectar by a syringe, a $5 \mathrm{ml}$ pipette was used. The nectar was then placed in a $15 \mathrm{ml}$ pharmaceutical glass vial and hermetically closed until chemical analysis.

Pollen was collected using pollen collectors, placed on the bee-entrance of the hive. Fresh pollen from the collector was transferred to $50 \mathrm{ml}$ plastic centrifuge tubes. Two equal samples were taken from each collector into separate tubes. Five-gram samples of pollen were used for the first chemical analyses. If the concentrations of neonicotinoids were below the detectable level, the measurements were repeated with $10 \mathrm{~g}$ of the same pollen sample. All samples were taken once in the middle of rape flowering.

In 2017 and 2018, besides nectar and pollen, the bee bread samples were also collected. For this purpose, a freshly-drawn honeycomb was inserted into the slope of the nest and marked with a marker. Samples of bee bread from these honeycombs were subsequently collected for the assessment of neonicotinoid residues from each hive.

Extracts from all the collected samples were made by using a solvent, then concentrated and filtered. The concentrated filtrate was analysed and residues of neonicotinoids determined by high-performance liquid chromatography (HPLC). The analyses were done at Kaunas University of Technology according to the methodology found in literature (Codling et al., 2016; Sánchez-Hernández et al., 2016). Chemical substances of chemically pure neonicotinoids were also used, according to which the device calibration was carried out.

Preparation of standard solutions. The main standard solutions were prepared in $1000 \mu \mathrm{g} \mathrm{ml}{ }^{-1}$ concentration by dissolving the compound in acetonitrile. The prepared solutions were kept in dark glass containers at $-18^{\circ} \mathrm{C}$. The working standard pesticide mixture was prepared by diluting the basic standard solutions with acidified acetonitrile $(0.1 \% \mathrm{HOAc})$ to $10 \mu \mathrm{g} \mathrm{ml}^{-1}$. This solution was stored at $4^{\circ} \mathrm{C}$ until application. By dilution of acetonitrile from the working mixture, standards were prepared for calibration curve and reinforcement. Triphenyl phosphate (TPP) was dissolved in $0.1 \%$ HOAc $0.5 \mu \mathrm{g} \mathrm{ml}^{-1}$ concentration and was added to final extracts, blank samples and matrix for calibration. Dissolved organophosphate triesters tris-(1,3-dichloro-2-propyl) phosphate (TDCPP) with acetonitrile $\left(50 \mu \mathrm{g} \mathrm{ml} \mathrm{m}^{-1}\right)$ was added to the samples to test the extraction.

Preparation of samples. The samples were prepared according to the modified QuEChERS (quick, easy, cheap, effective, rugged and safe) methodology as follows: 1) a 5 or $10 \mathrm{~g}$ sample was weighed into a Teflon centrifuge tube; 2) $100 \mu \mathrm{l}$ of TDCPP standard was added and the tube was shaken for $1 \mathrm{~min}$; 3) $10 \mathrm{ml}$ of the deionized water was added and the tube was shaken again 
for $20 \mathrm{~s}$; 4) $10 \mathrm{ml}$ of acetonitrile and $2 \mathrm{ml}$ of n-hexane was added and the tube was shaken again for $1 \mathrm{~min}$; 5) $4 \mathrm{~g}$ of anhydrous magnesium sulphate $\left(\mathrm{MgSO}_{4}\right), 1 \mathrm{~g}$ of sodium chloride $(\mathrm{NaCl}), 1 \mathrm{~g}$ of sodium citrate $\left(\mathrm{Na}_{3} \mathrm{C}_{6} \mathrm{H}_{5} \mathrm{O}_{7}\right)$, $0.5 \mathrm{~g}$ of sodium hydrochloride $(\mathrm{NaClO})$ were added and the tube was shaken manually for $1 \mathrm{~min}$ to prevent the formation of $\mathrm{MgSO}_{4}$ agglomerates; 6) the tube was centrifuged for $5 \mathrm{~min}$ at $7100 \times \mathrm{rpm}$; 7) $1 \mathrm{ml}$ of acetonitrile was transferred from the tube to a dispersive solid phase extraction (dSPE) tube with $240 \mathrm{mg}$ anhydrous $\mathrm{MgSO}_{4}$, $50 \mathrm{mg}$ PSA (primary secondary amine) and $50 \mathrm{mg}$ of C18 sorbents. The extract was mixed well and shaken for $1 \mathrm{~min}$; 8) dSPE tube was centrifuged for $1 \mathrm{~min}$ at $8600 \times \mathrm{rpm}$; 9) $250 \mu \mathrm{l}$ of extract was transferred to the Ependorf tube (VWR International, USA), $750 \mu$ water, $50 \mu \mathrm{l}$ acetonitrile and $50 \mu \mathrm{l}$ of the internal standard TPP solution were added. All was well mixed and filtered using a $0.45 \mu \mathrm{m}$ membrane filter in a HPLC vial. The solution obtained was analysed using the LC-MS/ MS (liquid chromatography-triple quadrupole mass spectrometry) method.

Liquid chromatography-mass spectrometry (LC-MS) analysis was carried out using the H class UPLC chromatograph with the TQ-S tandem mass spectrometer (Waters, USA). The compounds analysed were divided by a column of Acquity C18 $(100 \times 2.1 \mathrm{~mm})$ with a sorbent particle size of $1.7 \mu \mathrm{m}$ (Waters). The temperature of the column during the analysis was maintained at $45^{\circ} \mathrm{C}$. The volume of the inlet sample was $10 \mu \mathrm{l}$. The distribution was carried out using the following eluents: A - water with $0.01 \%$ formic acid and $5 \mathrm{mM}$ ammonium format; B - acetonitrile and water mixture (95:5) with $0.01 \%$ formic acid and $5 \mathrm{mM}$ ammonium format. The gradient of the eluents was as follows: the distribution began at $20 \% \mathrm{~B}$ and thus was maintained for $1 \mathrm{~min}$, followed by a concentration of B after $18 \mathrm{~min}$ increased to $100 \%$ and thus maintained for $2 \mathrm{~min}$. The total distribution time was $20 \mathrm{~min}$, after the gradient was returned to initial composition after $1 \mathrm{~min}$ and let settle down for $7 \mathrm{~min}$. The eluent flow rate of the eluents used for the analysis was $0.3 \mathrm{ml} \mathrm{min}{ }^{-1}$. The split compounds were analysed by a mass spectrometer with a triple quadrupole mass analyser. The analysis was carried out using the positive ionization of electrospray ionization (ESI) compounds. The following mass spectrometer parameters were used: ion source voltage $20 \mathrm{~V}$, capillary voltage $1500 \mathrm{~V}$, drying gas flow $10001 \mathrm{~h}^{-1}$ and infantry gas flow $1501 \mathrm{~h}^{-1}$. Drying temperature was $450^{\circ} \mathrm{C}$. Expulsion gas pressure was 7 bars. The quantitative analysis was carried out according to the inherent fractures of the compounds. Minimal detectable value of neonicotinoids was determined $0.1 \mathrm{ng} \mathrm{g}^{-1}$.

Degradation of thiamethoxam and clothianidin in the soil and determination of their residues in dust. In 2016 and 2017, soil dust was sampled using a film splashed with a sticky substance, liquid vaseline. Soil dust was scratched with a plastic shovel and collected. The residues of thiamethoxam and clothianidin were determined according to the same methodology as in the pollen samples.

In 2017, the collection of soil dust was optimised by adjusting $2 \times 2 \mathrm{~m}$ polyethylene film on the sowing unit, which contained a sticky substance with a $10 \mathrm{~cm}$ strap of grinding silicone that is particularly resistant to environmental and chemical effects. Immediately after sowing, silicone with dust was carefully collected using plastic confectionery tinplate. The dusting assessment was carried out on the $19^{\text {th }}$ of May 2017, when sowing the spring rape cultivar 'Fenja', whose seeds had been treated with the insecticide thiamethoxam $280 \mathrm{~g} \mathrm{l}^{-1}+$ fludioxonil $8.0 \mathrm{~g} \mathrm{l}^{-1}+$ metalaxyl-M $32.3 \mathrm{~g} \mathrm{l}^{-1}$ and seed coating agent Sepiret PF 16 (Sygenta, USA, and BASF, USA).

In 2017 , in order to determine the effects of dusting, 5 newly formed bee nucleus colonies were brought in during the spring rape sowing. They were formed in 2017 from the colonies intending to swarm. The colonies had three frames of bees and a virgin queen. They were placed $100 \mathrm{~m}$ away from the spring rape field being sowed.

In 2018, for more accurate and complex assessment of the potential adverse effects of dust on bee colonies, the same test for colonies was used as for the evaluation of neonicotinoid effects during flowering. Strong bee colonies were observed during the sowing of winter rape in 2017 and the spring rape in 2018, which were brought long before, thus eliminating the stress factor for colonies due to transportation.

The effects of neonicotinoids on bee vitality and health. The toxicity of neonicotinoid seed treatment to bees was evaluated in 2017 and 2018 by estimating the following parameters: 1) development of bee colonies during and after honey flow; the size of the bee colonies was measured at the beginning of the honey flow, 1 month after rape flowering and before wintering; the strength of colonies was estimated by the number of frames with bees, based on assessment scale from 1 to 20 , where 1-4 means poor, 5-8 - fair, 9-12 - good, 13-16 very good and 17-20 excellent colony strength; 2 ) bee productivity (kg of honey per colony); 3) bee health; assessment of mite infestation level in percent and possible external symptoms of diseases (chalkbrood, bees with deformed wings, etc.).

The mite infestation level was evaluated by using a sugar powder method. The bees were shaken down in a 0.9 -liter jar and covered with a $3 \times 3 \mathrm{~mm}$ metallic sieve. Then, a few tablespoons of sugar powder were applied directly on the bees through the sieve. Bees, coated with sugar powder, were shaking vigorously for about $1 \mathrm{~min}$ and all mites were separated by shaking the jar. The fallen mites were counted and the total mite infestation percentage was calculated. The presence of external symptoms of other diseases, including chalkbrood, pests, rots and viral infection was evaluated. Additionally, condition of queen bees, bee health (parasitic load) and productivity were evaluated in 2017 and 2018.

The status of queen bees was evaluated as follows: young, mated queen bees before their entry into the colony were marked with coloured fast-dry car paint. In the autumn before feeding, the status of those queen bees was evaluated as well as whether the queen bee was replaced or not.

Statistical analysis. The data were processed using the software Statistica, version 12 (StatSoft Inc., USA). The selected statistical significance level $p$ (the probability that the observed effect size is random) is 0.05 . The lower the value of the $p$, the smaller the probability that the resulting effect was accidental. 


\section{Results and discussion}

Due to the particularly poor weather in the summer of 2016, the newly created bee colonies did not yield marketable production. Residues of neonicotinoids were detected in the crops where the used insecticide had been applied for seed treatment in 2016, but their amounts were insignificant. Therefore, the data from 2016 was not discussed in detail in the article.

Results of the research in 2017. None of the bee colonies died in the winter of 2016-2017. Bees started orientation flights late, at the end of March, in 2017, so the wintering took about 150 days. Bees had wintered well. The overwintering index was estimated to be close to 1 . The strength of bee colonies was rather similar; they occupied one Langstroth hive floor. Twelve almost equally strong colonies were selected from the 18 overwintered colonies. They were divided into two groups of 6 hives and transported to the experimental crops. In spring, in order to accelerate the development of bees, $2.5 \mathrm{~kg}$ of sugar powder candy dough was added to each colony. On May 10, 2017 the bee colonies were transported to the winter rape crops in Noreikiškès, Kaunas district. The strength and development of the bee colonies there are presented in Table 1.

Table 1. The status of the bee colonies located in the neonicotinoid seed-treated winter rape crop in 2017 (Noreikiškès, Kaunas distr.)

\begin{tabular}{lccccccc}
\hline \multicolumn{1}{c}{ Hive No. } & 1 & 2 & 35 & 88 & 106 & 147 & Average \\
\hline $\begin{array}{l}\text { Strength in spring, frames } \\
\text { with bees (23 May) }\end{array}$ & 9 & 10 & 10 & 10 & 10 & 10 & 9.83 \\
Strength before autumn feeding & - & 12 & 11 & 11 & 12 & 10 & 11.2 \\
Status of queen bee & drone layer & not replaced & superseded & superseded & superseded & not replaced & $\begin{array}{c}33 \% \text { not } \\
\text { replaced }\end{array}$ \\
Extracted honey kg & 0 & 45 & 45 & 40 & 50 & 18 & 33 \\
Varroa mite infestation level \% & - & 3 & 2 & 3 & 3 & 3 & 2.8 \\
\hline
\end{tabular}

Note. ${ }^{*}$ - average calculated from the colonies with honey production.

Table 1 shows that one bee colony became a drone layer and eventually collapsed. There was a high percentage of queen bees superseded, even though they were young, from the previous year. It can be assumed that neonicotinoids had a negative effect on queen bees' vitality and the reproductive system, which is why they were superseded during honey flow. From spring bee colonies developed well, so it is likely that only neonicotinoid-affected queen bees were replaced. This could have been because the royal jelly, which was fed to queen bees, was secreted by nurse bees out of the bee bread contaminated with traces of neonicotinoids.

A high swarming rate was observed in the spring rape crop, where 4 out of 6 colonies swarmed (Table 2).

Table 2. The status of the bee colonies located in the neonicotinoid seed-treated spring rape crop in 2017 (Paliepis, Kaišiadorys distr.)

\begin{tabular}{lccccccc}
\hline \multicolumn{1}{c}{ Hive No. } & 3 & 27 & 28 & 40 & 45 & 60 & Average \\
\hline $\begin{array}{l}\text { Strength in spring, frames } \\
\text { with bees (23 May) }\end{array}$ & 10 & 10 & 10 & 10 & 10 & 10 & 9.83 \\
Strength before feeding & 12 & 13 & 11 & 10 & 11 & 12 & 11.5 \\
Status of queen bee & not replaced & superseded & swarmed & swarmed & swarmed & swarmed & $\begin{array}{c}17 \% \text { not } \\
\text { replaced }\end{array}$ \\
Extracted honey kg & 60 & 45 & 50 & 30 & 35 & 55 & 45.83 \\
Varroa mite infestation level \% & 4 & 3 & 3 & 2 & 2 & 2 & 2.67 \\
\hline
\end{tabular}

Only in one colony the queen bee had not been replaced. It was also found that in Kaišiadorys district, the presence of neonicotinoid residue in bee bread made by bees from the spring rape pollen was higher than in the winter rape crop at Noreikiškès, Kaunas district (Fig. 1).

The mite load in the hives kept in the spring rape crop was slightly lower. Most likely it was due to the high swarming rate in the spring rape. Presumably, the swarming bees naturally cleaned themselves from mites thus improving health.

The status of the control bee colonies, which are considered to be kept under intensive farming conditions, is presented in Table 3. In the control bee colonies, bee productivity was lower $34 \mathrm{~kg}$ per colony. It was also found that in this group, queen bees were superseded less often compared to other bee colonies.

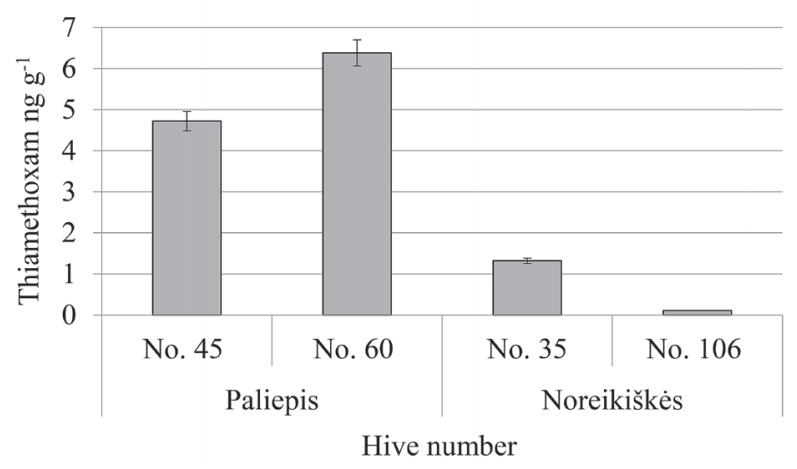

Note. Vertical bars represent standard deviation.

Figure 1. Residue levels of thiamethoxam in the bee bread samples in 2017 (Paliepis, Kaišiadorys distr., and Noreikiškès, Kaunas distr.) 
Table 3. The status of bee colonies in the control group in 2017 (Palimšys, Kaišiadorys distr.)

\begin{tabular}{lcccccc}
\hline \multicolumn{1}{c}{ Hive No. } & 19 & 29 & 31 & 32 & 34 & Average \\
\hline $\begin{array}{l}\text { Strength in spring, frames } \\
\text { with bees (19 May) }\end{array}$ & 8 & 10 & 9 & 10 & 10 & 10 \\
$\begin{array}{l}\text { Strength before feeding } \\
\text { Status of queen bee }\end{array}$ & 10 & 11 & 10 & 11 & 9.5 & 10 \\
Extracted honey kg & not replaced not replaced & swarmed & superseded & not replaced not replaced \\
Varroa mite infestation level \% & 40 & 30 & 20 & 30 & 40 & 45 \\
\hline
\end{tabular}

Results of the research in 2018. The colonies, in which samples with the largest concentrations of neonicotinoids were detected in 2017 survived the 20172018 winter very well. The strength of the bee colonies declined by over $10 \%$ during the winter. Bees were strong in spring, without symptoms of infection and diarrhoea. The colonies developed very well until the winter rape flowering and managed to exploit it for honey flow very well (Table 4).

The test group of the bee colonies kept in the spring rape crops in the 2018 at the Girele poultry farm in
Kaišiadorys was formed in 2017. The new colonies were transported to the territory of the Girele poultry farm in August 2017 to obtain the representative data. The data on the status of bee colonies in this group is presented in Table 5. The colony strength in the spring of 2018 was much greater than in 2017. Average colony strength in the spring of 2017 (before flowering) was 9.5 interspaces versus $11.8-15.7$ in 2018. This huge difference in colony strength between years could be explained by the contrasting meteorological conditions in the spring of 2017 and 2018.

Table 4. The status of the bee colonies located in the neonicotinoid seed-treated winter rape crop in 2018 (Paliepis, Kaišiadorys distr.)

\begin{tabular}{ccccccccc}
\hline $\begin{array}{c}\text { Hive } \\
\text { No. }\end{array}$ & $\begin{array}{c}\text { Strength } \\
\text { before } \\
\text { wintering }\end{array}$ & $\begin{array}{c}\text { Strength } \\
\text { after } \\
\text { wintering }\end{array}$ & $\begin{array}{c}\text { Wintering } \\
\text { index }\end{array}$ & $\begin{array}{c}\text { Strength } \\
\text { in spring, } \\
\text { 30 April }\end{array}$ & $\begin{array}{c}\text { Queen bee status } \\
\text { after honey } \\
\text { harvesting }\end{array}$ & $\begin{array}{c}\text { Mite infestation } \\
\text { level \% } \\
\text { in August }\end{array}$ & $\begin{array}{c}\text { Productivity } \\
\text { kg }\end{array}$ & $\begin{array}{c}\text { Strength } \\
\text { after feeding, } \\
\text { 20 September }\end{array}$ \\
\hline 3 & 9 & 9 & 1.00 & 15 & not replaced & 4 & 60 & 9 \\
27 & 8 & 7 & 0.88 & 16 & not replaced & 8 & 35 & 7 \\
28 & 10 & 9 & 0.90 & 14 & swarmed & 2 & 22 & 7 \\
40 & 10 & 9 & 0.90 & 16 & not replaced & 4 & 48 & 10 \\
45 & 9 & 8 & 0.88 & 18 & not replaced & 4 & 52 & 10 \\
60 & 8 & 7 & 0.88 & 15 & not replaced & 5 & 15 & 8 \\
76 & 10 & 8 & 0.80 & 16 & not replaced & 3 & 56 & 9 \\
\hline Aver- & 9.1 & 8.1 & 0.9 & 15.7 & $87.5 \%$ not replaced & 4.3 & 41.1 & 8.6 \\
age & & & &
\end{tabular}

Table 5. The status of the bee colonies located in the neonicotinoid seed-treated spring rape crop in 2018 (Girele poultry farm, Kaišiadorys)

\begin{tabular}{|c|c|c|c|c|c|c|}
\hline $\begin{array}{l}\text { Hive } \\
\text { No. }\end{array}$ & $\begin{array}{l}\text { Strength } \\
\text { after } \\
\text { wintering }\end{array}$ & $\begin{array}{l}\text { Strength } \\
\text { in spring, } \\
5 \text { May }\end{array}$ & $\begin{array}{c}\text { Queen bee status } \\
\text { after honey } \\
\text { harvesting }\end{array}$ & $\begin{array}{c}\text { Mite infestation } \\
\text { level \% } \\
\text { in August }\end{array}$ & $\begin{array}{l}\text { Productivity } \\
\mathrm{kg}\end{array}$ & $\begin{array}{l}\text { Strength after } \\
\text { feeding, } \\
20 \text { September }\end{array}$ \\
\hline 113 & 8 & 14 & not replaced & 3 & 82 & 10 \\
\hline 114 & 8 & 13 & not replaced & 2 & 75 & 9 \\
\hline 115 & 9 & 15 & not replaced & 3 & 81 & 9 \\
\hline 116 & 8 & 13 & not replaced & 4 & 77 & 8 \\
\hline 117 & 7 & 14 & not replaced & 3 & 86 & 9 \\
\hline 118 & 8 & 16 & not replaced & 2 & 92 & 10 \\
\hline 119 & 9 & 15 & not replaced & 3 & 52 & 9 \\
\hline 122 & 7 & 13 & not replaced & 4 & 58 & 9 \\
\hline 126 & 9 & 14 & superseded & 3 & 74 & 8 \\
\hline 133 & 8 & 13 & drone layer & 3 & 68 & 7 \\
\hline Average & 8.1 & 14.0 & $\begin{array}{c}80.0 \% \\
\text { not replaced }\end{array}$ & 3 & 74.5 & 8.8 \\
\hline
\end{tabular}

The control bee colonies at Noreikiškès, Kaunas district did not experience the negative effects of neonicotinoids, as within $1.5 \mathrm{~km}$ radius from the hives there were no intensive farming operations. The control bee colonies were slightly weaker than in both test groups and were developing slightly slower (Table 6). The honey production was slightly lower compared to the bee colonies located in neonicotinoid seed-treated winter rape crop and significantly lower than from the bee colonies located in the neonicotinoid seed-treated spring rape crop.

No effects of the neonicotinoids on bees were observed when assessing bee colonies at the time of sowing. It is noteworthy that there was a high concentration 
Table 6. The status of the bee colonies in the control group in 2018 (Noreikiškès, Kaunas distr.)

\begin{tabular}{ccccccc}
\hline $\begin{array}{c}\text { Hive } \\
\text { No. }\end{array}$ & $\begin{array}{c}\text { Strength } \\
\text { after wintering }\end{array}$ & $\begin{array}{c}\text { Strength } \\
\text { in spring, } \\
\text { 30 April }\end{array}$ & $\begin{array}{c}\text { Queen bee status } \\
\text { after honey } \\
\text { harvesting }\end{array}$ & $\begin{array}{c}\text { Mite infestation } \\
\text { level \% } \\
\text { in August }\end{array}$ & $\begin{array}{c}\text { Productivity } \\
\text { kg }\end{array}$ & $\begin{array}{c}\text { Strength after } \\
\text { feeding, } \\
\text { 20 September }\end{array}$ \\
\hline 4 & 7 & 11 & not replaced & 4 & 35 & 8 \\
86 & 8 & 12 & not replaced & 3 & 43 & 9 \\
145 & 8 & 13 & not replaced & 2 & 27 & 8 \\
179 & 9 & 12 & superseded & 3 & 21 & 7 \\
159 & 6 & 11 & not replaced & 2 & 54 & 87 \\
18 & 8 & 12 & not replaced & 3 & 37.8 & 8.3 \\
\hline Average & 7.7 & 11.8 & $83.3 \%$ & 2.8 & \\
\hline
\end{tabular}

of neonicotinoid residues in the soil dust. In the spring of 2017, in the Paliepis group, sowing was carried out about 15-20 meters from the hives. However, the prevailing western wind and a good hive location with a sufficient shelter probably prevented any dust from entering the hives. During the spring rape sowing in 2018, the hives were 200 meters from the sowing field, and the hives also had a shelter. We can conclude that in the absence of the natural barrier it is possible to protect the bees for a short period of time (while the sowing process takes place) when the hive-entrance is closed. Farmers should use accurate sowing machines to minimise dust release into the environment. In addition, to prevent dusting and the resulting neonicotinoid residues in the air, the treated spring rape seed should be sown in a moist soil, which was the case in our experiment in August 2016 at winter rape sowing. The prevailing wind direction should also be taken into account.

In 2017, 14 samples of bee bread were collected for neonicotinoid residue assessment. The residues were detected in eight of the samples: in four samples collected from the hives standing in Noreikiškès, Kaunas district, and in four samples collected from Paliepis, Kaišiadorys district (Fig. 1). The findings show that the concentration of neonicotinoid residues in the spring rape bee bread was significantly higher than in the winter rape bee bread. In spring rape, neonicotinoid decrease compared to winter rape is lower due to the shorter degradation period and potential. This explains why larger amounts of neonicotinoid residues were detected in the bee bread collected by bees from the spring rape pollen. Neonicotinoids are characterized by transformations, they breakdown in the natural conditions (Nauen et al., 2003).

It should be noted that clothianidin was not detected in any of the investigated samples, although rape was treated with both substances. It is known from the literature that neonicotinoids are metabolized, while entering plants or insect organisms, and thus one neonicotinoid can easily be converted into another (Nauen et al., 2003). The absence of clothianidin in any sample of bee bread or honey is associated with the same transformations.

Thiamethoxam and clothianidin residues were not detected in the analysed 20 honey samples collected in 2017. It should be emphasized that even the honey samples, taken from the hives where neonicotinoid residues had been found in the bee bread, contained no residues.

Nineteen samples of bee bread were collected in 2018 for analysis of neonicotinoid residues, 9 of them from the Girele poultry farm group, 7 from the Paliepis group, Kaišiadorys district, and 3 from the control group in Noreikiškès, Kaunas district. Residues of thiamethoxam were detected in 7 of the total samples tested: 6 from the hives standing in spring rape at Kaišiadorys and 1 in winter rape at Paliepis, Kaišiadorys district (Fig. 2). Neonicotinoid residues were not detected in the control group. It should be noted that clothianidin was not found in any of the tested samples.

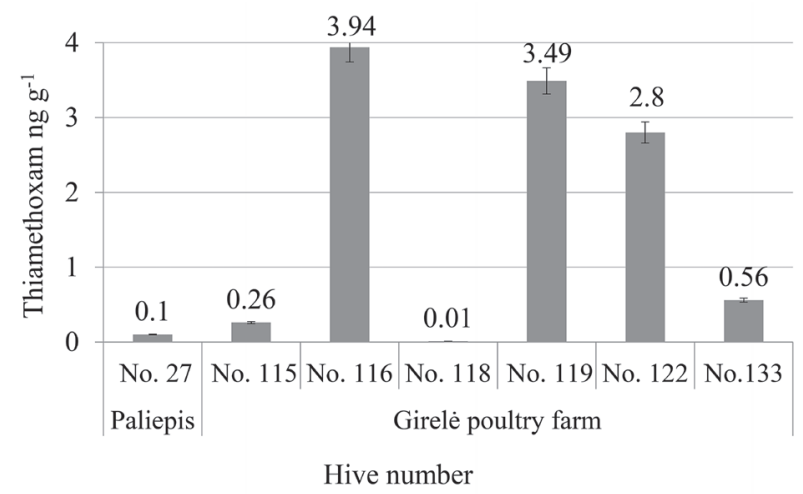

Note. Vertical bars represent standard deviation.

Figure 2. Residue levels of thiamethoxam in the bee bread samples in 2018 (Paliepis, Kaišiadorys distr., and Girelè poultry farm, Kaišiadorys)

In pollen samples collected from winter and spring rape crops in 2017-2018 there were no neonicotinoid residues detected. It is very difficult to identify the time when neonicotinoid residues appear in pollen loads, collecting pollen only once or twice during the flowering period.

Chemical analyses were aimed at determining the potential residues of thiamethoxam and clothianidin in the honey and bee bread samples taken from the test hives. Only thiamethoxam was found in bee bread samples. Its largest quantities in 2017 were found in the bee bread, taken from the hives standing in the fields of Paliepis, Kaišiadorys district: No. $60-6.38 \pm 0.51 \mathrm{ng} \mathrm{g}^{-1}$ and No. $454.72 \pm 0.43 \mathrm{ng} \mathrm{g}^{-1}$, while in the samples of the bee bread from the hives standing in Noreikiškès, Kaunas district, the levels of residues were lower: No. $35-1.32 \pm$ $0.29 \mathrm{ng} \mathrm{g}^{-1}$ and No. $106-0.11 \pm 0.01 \mathrm{ng} \mathrm{g}^{-1}$. Statistically significant differences in the thiamethoxam amount in the bee bread $(p<0.05)$ were found between the test sites.

The highest concentration of thiamethoxam was found in the bee bread taken from the hives standing in the fields of the Girele poultry farm in the spring rape: No. $116-3.94 \pm 0.27 \mathrm{ng} \mathrm{g}^{-1}$, No. $119-3.49 \pm$ 
$0.24 \mathrm{ng} \mathrm{g}^{-1}$ and No. $122-2.80 \pm 0.09 \mathrm{ng} \mathrm{g}^{-1}$. The lowest concentration was also observed there in the bee bread sample from hive No. $118-0.01 \pm 0.01 \mathrm{ng} \mathrm{g}^{-1}$. In one bee bread sample from the winter rape crop from Paliepis, Kaišiadorys district, thiamethoxam was found - No. 27 $-0.10 \pm 0.01^{-1}$. Statistically significant differences in thiamethoxam amount in bee bread $(p<0.05)$ were found between these test sites.

Despite the detection of thiamethoxam residues, such bee bread is suitable for human consumption because the maximum levels are limited to $0.05 \mathrm{mg} \mathrm{kg}^{-1}$ (Commission Regulation (EU) 2017/671).

A total of 10 honey samples were taken in 2018 . Thiamethoxam was not found in the honey samples from the hives in Paliepis, Kaišiadorys district, while it was detected in 4 out of 5 honey samples taken from the hives standing in the fields of Girele poultry farm. The highest concentrations were determined in hives No. $113-3.03 \pm 0.08 \mathrm{ng} \mathrm{g}^{-1}$, No. $119-2.72 \pm 0.13 \mathrm{ng} \mathrm{g}^{-1}$ No. $126-1.77 \pm 0.03 \mathrm{ng} \mathrm{g}^{-1}$ and No. $133-0.26 \pm 0.07$ $\pm 0.07 \mathrm{ng} \mathrm{g}^{-1}$. Clothianidin was not detected. Unlike in 2017, thiamethoxam was found in the bee bread and honey samples taken from the same hive (Nos 119 and 123 ) in the Girele poultry farm. However, like the bee bread, the honey is also suitable for human consumption, because the amounts of thiamethoxam found in it did not exceed the maximum permitted concentration of $0.05 \mathrm{mg} \mathrm{kg}^{-1}$ (Commission Regulation (EU) 2017/671).

When treating with low concentrations, pesticide residues are transported throughout the plant and only small concentrations of residue reach nectar and pollen at flowering. Apparently, part of the seed treatment pesticide in the plant is broken down by various mechanisms before flowering. The residues found in the nectar are also partly detoxified by the cytochrome phosphate detoxification system in the mitochondria of bees.

The results of the residue analysis suggest that nectar, most likely due to its hydrophilic structure, accumulates the residues of thiamethoxam and clothianidin. Other pesticides are more commonly found in bee bread than nectar. It is apparent from the research that thiamethoxam in many cases was detected significantly more frequently and at higher concentrations than clothianidin in pollen, honey and bee bread samples. It should also be noted that the determined concentration of clothianidin in all seed samples was 5 to 10 times greater than that of thiamethoxam. Clothianidin in treated seed was found at concentrations ranging from 38 to $12434 \mathrm{ng} \mathrm{g}^{-1}$, and thiamethoxam - from 3.5 to $2130 \mathrm{ng} \mathrm{g}^{-1}$. However, higher residue levels of thiamethoxam always prevail in bee products. There is a logical contradiction here. This discrepancy can be explained in a twofold manner. Firstly, clothianidin is significantly less likely to accumulate in nectar and pollen than thiamethoxam. Secondly, clothianidin degradation half-life in rape plants may be significantly faster than that of thiamethoxam. This may affect plant (rape) physiological metabolic adaptation processes and may be the reason why clothianidin can be metabolised faster than thiamethoxam.

Residue levels of neonicotinoids in the soil dust. In 2017, after improvement in dust catching methodology, the concentration of thiamethoxam in the soil dust, released during the sowing operation was $162.42 \pm 1.7 \mathrm{ng} \mathrm{g}^{-1}$. Thiamethoxam might have been detected in 2017 due to the meteorological conditions, i.e. on the sowing day and a week before, the weather was dry and warm, which resulted in dusting during sowing, while in 2016 the weather was rainy. In any case, it is important to emphasize dusting mitigation measures, such as the use of dampers, air recirculation systems, and high quality seeds; all this helps to reduce dustiness, and hence to avoid the negative potential impact on bees.

\section{Conclusions}

1. The study found that when neonicotinoid-treated winter and spring rape seed was sown in a dry soil, the concentrations of neonicotinoids in the dust released during the sowing operation were three times as high as the maximum permitted limit $\left(0.05 \mathrm{mg} \mathrm{kg}^{-1}\right)$ set by the European Committee for bee products. However, no evidence was found to indicate the negative effects of the nicotinoid-seed treatment on the further development of honey bee colonies, wintering, well-being and honey production.

2. The analysis of neonicotinoid residues in pollen, nectar and bee bread showed that thiamethoxam residues were found at higher concentrations and at higher frequencies than those of clothianidin. The highest residue levels of both neonicotinoids, identified in the bee products tested in 2016-2018 (mainly found in the bee bread), were 7 times lower than the maximum EU permitted concentration of $0.05 \mathrm{mg} \mathrm{kg}^{-1}$.

3 . Observations of the fully-developed honey bee colonies in 2017-2018 showed the possible negative effect of the neonicotinoids on the queen bees. The effect manifested itself by the supersedure of queen bees in the summer, which may have depended on the pesticide residue levels in the bee food.

\section{Acknowledgements}

This paper presents research findings obtained through the long-term research project "Monitoring of the effects of winter and spring rape seed treatment with neonicotinoids on bees", funded by the Ministry of Agriculture of the Republic of Lithuania.

Received 17122018

Accepted 22032019

\section{References}

1. Brittain C., Kremen C., Klein A. M. 2013. Biodiversity buffers pollination from changes in environmental conditions. Global Change Biology, 19 (2): 540-547. https://doi.org/10.1111/gcb.12043

2. Codling G., Al Naggar Y., Giesy J. P., Robertson A. J. 2016. Concentrations of neonicotinoid insecticides in honey, pollen and honey bees (Apis mellifera L.) in central Saskatchewan, Canada. Chemosphere, 144: 2321-2328. https://doi.org/10.1016/j.chemosphere.2015.10.135

3. Commission Regulation (EU) 2017/671 of 7 April 2017 amending Annex II to Regulation (EC) No 396/2005 of the European Parliament and of the Council as regards maximum residue levels for clothianidin and thiamethoxam in or on certain products. https://eur-lex.europa.eu/legalcontent/GA/TXT/?uri=CELEX:32017R0671 
4. Elbert A., Haas M., Springer B., Thielert W., Nauen R. 2008. Applied aspects of neonicotinoid uses in crop protection. Pest Management Science, 64: 1099-1105. https://doi.org/10.1002/ps.1616

5. Feltham H., Park K., Goulson D. 2014. Field realistic doses of pesticide imidacloprid reduce bumblebee pollen foraging efficiency. Ecotoxicology, 23: 317-323. https://doi.org/10.1007/s10646-014-1189-7

6. Fogel M. N., Schneider M. I., Desneux N., González B., Ronco A. E. 2013. Impact of the neonicotinoid acetamiprid on immature stages of the predator Eriopis connexa (Coleoptera: Coccinellidae). Ecotoxicology, 22: $1063-1071$. https://doi.org/10.1007/s10646-013-1094-5

7. Garibaldi L. A., Dewenter I. S., Winfree R., Aizen M. A., Bommarco R. 2013. Wild pollinators enhance fruit set of crops regardless of honey bee abundance. Science, 339: $1608-1611$.

8. Hayasaka D., Korenaga T., Suzuki K., Saito F., SánchezBayo F. 2012. Cumulative ecological impacts of two successive annual treatments of imidacloprid and fipronil on aquatic communities of paddy mesocosms. Ecotoxicology and Environmental Safety, 80: 355-362. https://doi.org/10.1016/j.ecoenv.2012.04.004

9. Heimbach F., Russ A., Schimmer M., Born K. 2016. Large-scale monitoring of effects of clothianidin dressed oilseed rape seeds on pollinating insects in Northern Germany: implementation of the monitoring project and its representativeness. Ecotoxicology, 25: 1630. https://doi.org/10.1007/s10646-016-1724-9

10. Jeschke P., Nauen R., Schindler M., Elbert A. 2011. Overview of the status and global strategy for neonicotinoids. Journal of Agricultural and Food Chemistry, 59: 2897-2908. https://doi.org/10.1021/jf101303g

11. Karise R., Raimets R., Bartkevics V., Pugajeva I., Pihlik P., Keres I., Williams I. H., Viinalass H., Mänd M. 2017. Are pesticide residues in honey related to oilseed rape treatments? Chemosphere, 188: 389-396.

https://doi.org/10.1016/j.chemosphere.2017.09.013

12. Kleijn D., Winfree R., Potts S. 2015. Delivery of crop pollination services is an insufficient argument for wild pollinator conservation. Nature Communications, 6: 7414.

13. Lu C., Warchol K. M., Callahan R. A. 2012. In situ replication of honey bee colony collapse disorder. Bulletin of Insectology, 65: 99-106.

14. Lu C., Warchol K. M., Callahan R. A. 2014. Sublethal exposure to neonicotinoids impaired honey bees winterization before proceeding to colony collapse disorder. Bulletin of Insectology, 67: 125-130.

15. Maini S., Medrzycki P., Porrini C. 2010. The puzzle of honey bee losses: a brief review. Bulletin of Insectology, 63: $153-160$.

16. Matsumoto T. 2013. Short-and long-term effects of neonicotinoid application in rice fields, on the mortality and colony collapse of honeybees (Apis mellifera). Journal of Apicultural Science, 57: 21-35. https://doi.org/10.2478/jas-2013-0014

17. Nauen R. Ebbinghaus-Kintscher U., Vincent L., Salgado V. L., Kaussmannb M. 2003. Thiamethoxam is a neonicotinoid precursor converted to clothianidin in insects and plants. Pesticide Biochemistry and Physiology, 76: 55. https://doi.org/10.1016/s0048-3575(03)00065-8

18. Ollerton J., Erenler H., Edwards M., Crockett R. 2014. Extinctions of aculeate pollinators in Britain and the role of large-scale agricultural changes. Nature, 346: 1360-1362. https://doi.org/10.1126/science.1257259
19. Potts S. G., Biesmeijer J. C., Kremen C., Neumann P., Schweiger O., Kunin W. E. 2010. Global pollinator declines: trends, impacts and drivers. Trends in Ecology and Evolution, 25: 345-353.

https://doi.org/10.1016/j.tree.2010.01.007

20. Rolke D., Persigehl M., Peters B., Sterk G., Blenau W. 2016. Large-scale monitoring of effects of clothianidin dressed oilseed rape seeds on pollinating insects in northern Germany: residues of clothianidin in pollen, nectar and honey. Ecotoxicology, 25 (9): 1691-1701. https://doi.org/10.1007/s10646-016-1723-x

21. Sanchez-Bayo F., Tennekes A. H., Goka K. 2013. Impact of systemic insecticides on organisms and ecosystems. Trdan S. (ed.). Insecticides - development of safer and more effective technologies, p. 365-414. https://doi.org/10.5772/52831

22. Sánchez-Hernández L., Hernández-Domínguez D., Martín M. T., Nozal M. J., Higes M., Bernal Yagüe J. L. 2016. Residues of neonicotinoids and their metabolites in honey and pollen from sunflower and maize seed dressing crops. Journal of Chromatography A, 1428: 220-227. https://doi.org/10.1016/j.chroma.2015.10.066

23. Schmuck R., Lewis G. 2016. Review of field and monitoring studies investigating the role of nitrosubstituted neonicotinoid insecticides in the reported losses of honey bee colonies (Apis mellifera). Ecotoxicology, 25 (9): 1617-1629. https://doi.org/10.1007/s10646-016-1734-7

24. Simon-Delso N., Amaral-Rogers V., Belzunces L. P., (...), Wiemers M. 2015. Systemic insecticides (neonicotinoids and fipronil): trends, uses, mode of action and metabolites. Environmental Science and Pollution Research, 22 (1): 5-34.

https://doi.org/10.1007/s11356-014-3470-y

25. Sterk G., Peters B., Gao Z., Zumkier U. 2016. Large-scale monitoring of effects of clothianidin-dressed OSR seeds on pollinating insects in Northern Germany: effects on large earth bumble bees (Bombus terrestris). Ecotoxicology, 25 (9): 1666-1678.

https://doi.org/10.1007/s10646-016-1730-y

26. Van der Sluijs J. P., Simon-Delso N., Goulson D., Maxim L., Bonmatin J.-M., Belzunces L. P. 2013. Neonicotinoids, bee disorders and the sustainability of pollinator services. Current Opinion in Environmental Sustainability, 5: 293-305. https://doi.org/10.1016/j.cosust.2013.05.007

27. Winfree R., Aguilar R., Vazquez D. P., LeBuhn G., Aizen M. A. 2009. A meta-analysis of bees' responses to anthropogenic disturbance. Ecology, 90: 2068-2076. https://doi.org/10.1890/08-1245.1

28. Woodcock B. A., Harrower C., Redhead J., Edwards M., Vanbergen A. J., Heard M. S., Roy D. B., Pywell R. F. 2014. National patterns of functional diversity and redundancy in predatory ground beetles and bees associated with key UK arable crops. Journal of Applied Ecology, 51: 142-151. https://doi.org/10.1111/1365-2664.12171

29. Woodcock B. A., Bullock J. M., Shore R. F., Heard M. S., Pereira M. G., Redhead J., Ridding L., Dean H., Sleep D., Henrys P., Peyton J., Hulmes S., Hulmes L., Sárospataki M., Saure C., Edwards M., Genersch E., Knäbe S., Pywell R. F. 2017. Country-specific effects of neonicotinoid pesticides on honey bees and wild bees, Science, 356 (6345): 1393-1395.

https://oi.org/10.1126/science.aaa1190 
ISSN 1392-3196 / e-ISSN 2335-8947

Zemdirbyste-Agriculture, vol. 106, No. 2 (2019), p. 173-182

DOI 10.13080/z-a.2019.106.023

\title{
Žieminių ir vasarinių rapsų sèklų beicavimo neonikotinoidais poveikis bitėms
}

\author{
R. Zemeckis ${ }^{1}$, A. Dautartè ${ }^{1}$, J. Kretavičius ${ }^{1}$, J. Droždz ${ }^{2}$ \\ ${ }^{1}$ Vytauto Didžiojo universiteto Žemès ūkio akademija \\ ${ }^{2}$ Vilniaus universitetas
}

\section{Santrauka}

Siekiant nustatyti neonikotinoidų (tiametoksamo ir klotianidino) galimą poveikị naminèms bitèms (Apis mellifera L.), tyrimas atliktas 2016-2018 m. Tyrimo tikslas - įvertinti neonikotinoidų klasei priklausančių veikliujų medžiagų, naudojamų rapsų sėkloms beicuoti, poveikį bitèms Lietuvos sąlygomis. Tyrimo metu buvo sukurtos bičių šeimos, nustatyti neonikotinoidų likučiai dirvožemio dulkèse sejjos metu, taip pat sukurtų šeimų surinktame nektare, bičių duoneleje ir žiedadulkèse.

2017 ir 2018 m. buvo nustatytas galimas poveikis normaliai išsivysčiusioms bičių šeimoms. Tyrimo metu nustatyta, kad neonikotinoidais beicuotus rapsus sėjant esant sausam dirvožemiui, su dirvožemio dulkèmis ị aplinką pateko neonikotinoidų likučių, kurių koncentracija bičių produktuose Europos Komisijos nustatytą leistiną maksimalų kieki $\left(0,05 \mathrm{mg} \mathrm{kg}^{-1}\right)$ viršijo daugiau kaip tris kartus. Meduje, žiedadulkèse ir bičių duonoje nustatytas minimalus kiekis $\left( \pm 0,01 \mathrm{ng} \mathrm{g}^{-1}\right)$ neonikotinoidų likučių. Nebuvo nustatyta, kad po sëjos ir medunešio sutriktų tolesnis bičių šeimų vystymasis, žiemojimas ir sveikatingumas.

Reikšminiai žodžiai: Apis mellifera, augalų apsauga, neonikotinoidai, pasèlių apdulkinimas, rizikos vertinimas. 